\title{
遺伝子からみたイリオモテヤマネコと ツシマヤマネコの渡来と進化起源
}

\author{
增田隆一* \\ Phylogeny and Evolutionary Origin of the Iriomote Cat and the \\ Tsushima Cat, based on DNA Analysis \\ Ryuichi MASUDA*
}

\begin{abstract}
The richness of fauna diversity is seen on the Japanese Islands, which range through $3,000 \mathrm{~km}$. When and from where have the animals immigrated to Japan? Also, for understanding natural history of the Japanese Islands, it is very important to investigate evolutinary history and origin of animals distributed on each island. While the evolutionary questions have been paleontologically and geologically examined so far, some of them are still unclear. Recent development of molecular phylogenetic study provides a reliable sight to understanding evolutionary history and origin of species. Advantageously, molecular study can analyze phylogeny of living species without fossil data.

In Japan, two wildcats, the Iriomote cat and the Tsushima cat, live on the Iriomote Island and the Tsushima Island, respectively, where land bridges between the Asian continent and the Japanese Islands were present in the past time. To know evolution of these wildcats gives us useful information for better understanding of natural history of the Japanese Islands. Moreover, because both the wildcats are now endangered, it is now strongly needed to understand phylogenetic status of them for conservation and management. For the reason, we investigated molecular phylongeny of the two wildcats based on mitochondrial DNA sequences, and revealed that both the wildcats are very closely related to the leopard cat Felis bengalensis, which is widespread throughout Asia. Furthermore, from the DNA data, the Iriomote cat and the Tsushima cat were estimated to have diverged from the continental leopard cat approximately 200,000 and 100,000 years before present, respectively. The dates estimated by molecular data were in concordance with formation dates of the Ryukyu Arc and the Tsushima Island, respectively. These results suggest that geographic barrier has led fixation of some unique morphological characters into each cat population, while the two Japanese wildcats are still genetically close to the continental leopard cat.
\end{abstract}

\footnotetext{
* 北海道大学理学部附属動物染色体研究施設

* Chromosome Research Unit, Faculty of Science, Hokkaido University
} 
Key words : Iriomote cat, Tsushima cat, mitochondrial DNA, molecular phylogeny, evolution, divergence time, geographic isolation

キーワード：イリオモテヤマネコ, ツシマヤマネコ, ミトコンドリアDNA, 分子系統, 進化, 分岐年代, 地理的隔離

\section{I. はじめに}

南北 $3,000 \mathrm{~km}$ 以上にわたって弧状に連なる日 本列島。その北端である北海道は亜寒帯の千島列 島につながり，南に点在する南西諸島は亜熱帯に まで及んでいる（図1）。そして，これらの弧状列 島は多様な生物相を有している。いったい，日本 列島の島々に分布する生き物たちは，いつ，どこ からやってきたのだろうか？

この進化の謎へのアプローチは, 従来, 日本列 島の古地理と化石記録に基づく研究によってなさ れてきた。しかし，最近では現在生きている生物 （現生種）の遺伝子（DNA）を比較解析すること により，その進化ルーツを解明したり種や集団の 分岐年代（あるいは渡来時期）を推定できるよう になった。このような遺伝子データに基づいて生 物の進化を探る研究分野を「分子系統学」とよん でいる。この新しい研究領域から得られる成果は, 従来の地質学的・古生物学的データと照らし合わ せることにより, 生物進化の謎解きに新しい光を 与えている。筆者らは, 分子系統学的解析に基づ き, 日本に分布する哺乳類の進化 - 起源と渡来時 期を探索している。

\section{II. 分子系統学とは}

分子系統学について, もう少し説明することに しょう。この学問分野において前提となることは, $\lceil 4$ 種の塩基（ $\mathrm{A}, \mathrm{G}, \mathrm{C}, \mathrm{T}$ ) によって構成される DNA は, 生命の誕生以来, 親から子へ脈々とうけ つがれてきた遺伝情報であり，そこには生物進化 の歴史が塩基の変化 (突然変異) として刻み込ま れている」ということである。つまり，DNA は 「分子化石」と考えることもできる。したがって， ある2つの生物種を比べた場合, DNA 塩基配列 のちがいが大きい程, 両種が種分化してからの時 間が長いこと, すなわち, 進化距離が離れている

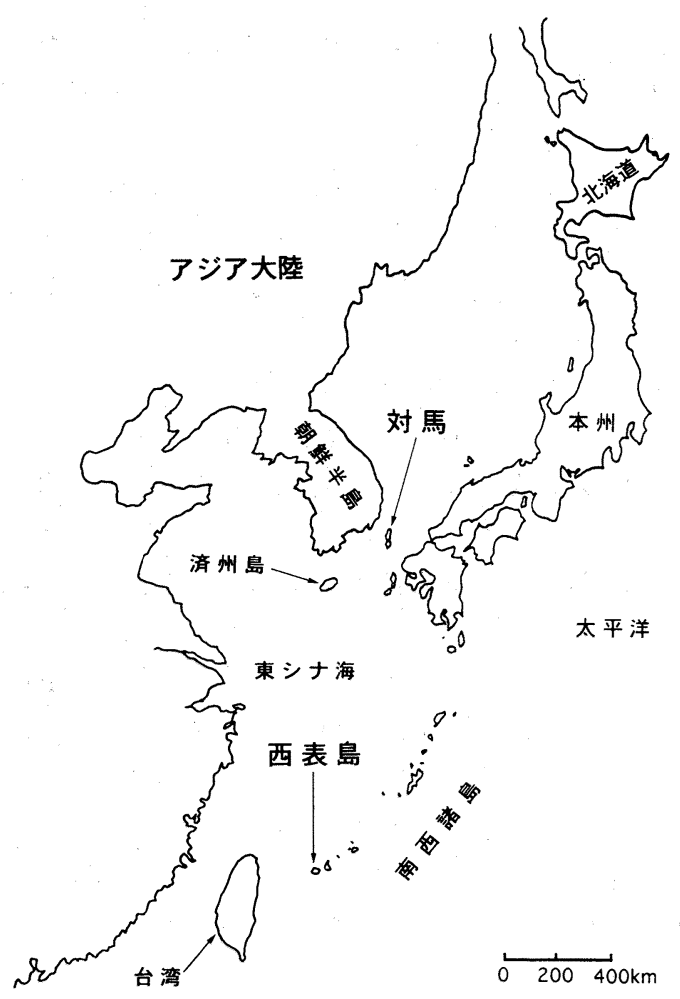

図 1 南北 $3,000 \mathrm{~km}$ 以上にわたって弧状に連なる 日本列島。

南西諸島の西表島および, 日本と朝鮮半島の 間に位置する対馬には, 各々イリオモテヤマ ネコ,ツシマヤマネコが生息している。

Fig. 1 Map of Japan Islands. The Iriomote cat and the Tsushima cat are distributed on Iriomote Island and Tsushima Island, respectively.

ことを意味しており，その距離は種の系統関係を 反映する。いわば, DNAのちがいを“ものさし” にして，生物間の距離を測るのである。また，比 べる生物が, たとえばネコ科の仲間, イヌ科の中 間というように，近縁種どうしであれば，注目す るDNA 領域において塩基が変化（置換）する速 さ（進化速度）は，ほぼ一定であることが知られ 
ている。この性質は「分子時計」とよばれる。進 化距離と分子時計に基づき, 生物間の分岐年代を 推定することができるのである。DNA デー夕に 基づいて地理的に隔離された島集団と大陸集団と の分岐年代を推定することは, その島と大陸が分 断された年代を分析する地質学分野にも重要な資 料を与えてくれる。さらに, 祖先化石のデー夕が ないような生物種についても, 分子系統学的手法 を導入することにより，その系統進化と分岐年代 を推定することができるという利点がある。

また, 最近の DNA 分析技術の発達は分子系統 学の発展にも大いに貢献している。特に, 遺伝子 増幅法 (PCR: polymerase chain reaction) (Mullis et al., 1986; Saiki et al., 1988)は, 微 量の生物組織（米粒程度の組織, 1滴の血液, 体毛 など）から分析可能な量まで DNA を増幅させる ことができる革命的技術である。PCR 法による 産物を用いた塩基配列決定法 (PCR 産物ダイレ クトシーケンス法) (Gyllensten and Erlich, 1988; Kocher et al., 1989)を用いることにより, 迅速に塩基配列を決定することができるようになっ た。そのため, PCR 産物ダイレクトシーケンス法 は, 系統樹作成法を含めた分子進化学的理論の進 展とともに, 分子系統学の急速な発展の一翼を担っ ている。

本稿では，筆者らが行なっているイリオモテヤ マネコおよびッシマヤマネコの分子系統と分岐年 代の推定に関する研究成果を紹介したい。

\section{III. 従来のイリオモテヤマネコとツシマヤマ ネコの系統分類学的位置}

わが国には，ネコ科としてイリオモテヤマネコ とッシマヤマネコの 2 種が生息しているが，その 進化と渡来については, これまでにも, アジア大 陸との関係から論議されてきた。しかし，いまた に明確な解答は得られていない。

イリオモテヤマネコは, 1965 年に南西諸島の西 表島においてその存在が確認された。Imaizumi （1967）は形態学的分析に基づき，このヤマネコ を新属新種 Mayailurus iriomotensis と命名した。 今泉ほか (1977) は, イリオモテヤマネコの頭骨
の特徵が中新世後期に中国大陸に出現したメタイ ルルス属 Metailurusに類似していることを指摘 し，イリオモテヤマネコは中新世後期から鮮新世 前期 (今からおよそ 1,000 万年から 500 万年前) にメタイルルス属から分かれたものとしている。 そして，イリオモテヤマネコがアジア大陸から西 表島へ渡来した時期を 300 万年以上前と想像して いる。また，イリオモテヤマネコは 1967 年国の 天然記念物に, 1972 年には特別天然記念物に指定 された。その後, Wurster-Hill et al. (1987) に よって，イリオモテヤマネコの核型（染色体数と 分染パターン）はベンガルヤマネコ Felis bengalensis のものと区別がつかない程一致して いることが報告された。ベンガルヤマネコはイン ドから東南アジア, 中国, 極東地域にかけたアジ ア大陸，および近隣の島々に広く分布するヤマネ コで，その形態の地域変異も多様であることが知 られている。東南アジアのベンガルヤマネコと比 ベると, イリオモテヤマネコの外観上の特徽は, 長い胴体, 短い脚と尾である。また，その体毛色 は暗い斑紋を伴う茶褐色であるのに対し, 東南ア ジアのベンガルヤマネコでは, 黄色の地に黒色斑 を伴っている。一方，これまでに海外の分類学者 からはネコ科の分類に関していくつかの報告がな されているが，それらの中で，イリオモテヤマネ コの分類学的位置は必ずしも定まったものではな い。Imaizumi (1967) によるイリオモテヤマネ コの 1 属 1 種説を採択しているのは Ewer (1973) のみで, 他の研究者はイリオモテヤマネコを独立 種 Felis（またはPrionailurus） iriomotensis と 認めながらも，イリオモテヤマネコとベンガルヤ マネコ Felis bengalensisを共通の属に分類して いる (Hemmer, 1978; Leyhausen, 1979; Nowak, 1991)。また, Wozencraft (1993) はイ リオモテヤマネコの形態的特徴がベンガルヤマネ コの種内変異内に入るものと考え, 両者を同種と している。このように，イリオモテヤマネコの系 統進化はいまだ明確には解明されていない。

一方, 長崎県の対馬には, わが国のもう 1 つの ヤマネコであるッシマヤマネコが生息している。 ツシマヤマネコは, 1966 年に長崎県の天然記念物 
に，1971 年には国の天然記念物に指定されている。 しかし, このツシマヤマネコについても, その系 統分類学的位置と進化はいまだに明らかにされて いない。ここで確認しておくべきことは, ツシマ ヤマネコはこれまでに,「独立亜種」とも「独立 種」とも認められたことがないことである。つま り, ツシマヤマネコは常に極東産ヤマネコ（英名: Amur cat）の“1集団”と考えられてきた。極 東産ヤマネコの特徵は, 東南アジア産ベンガルヤ マネコに比べて, 体が大きく, 体毛の斑紋が薄色 であることである。極東産ヤマネコが「南方系の ベンガルヤマネコ」の亜種 (F. bengalensis euptilura) とされるときは, ツシマヤマネコにも 同じ亜種名が与えられる。また, 極東産ヤマネコ が独立種 ( F. euptilura) とされれば, 自動的に ツシマヤマネコの学名もF. euptilura となってき た。このように, 大陸のヤマネコについても形態 的相違に基づき, bengalensis と euptiluraの分類 と系統進化が論議されてきたが，これまでに明確 な結論は出されていないのである。

\section{IV. イリオモテヤマネコとツシマヤマネコの 遺伝子解析と分子系統}

そこで筆者らは, イリオモテヤマネコおよびッ シマヤマネコの系統進化上の位置を明らかにする ため, 核 DNA より数倍以上速い進化速度をもつ (Brown et al., 1979) ミトコンドリア DNA （mtDNA）を“ものさし”にして，分子系統学的 解析を行なった。細胞核 DNA と比べた場合の mtDNA の特徵は，母系遺伝する，組み換えを起 こさない, 分子サイズが小さい，などの点である。 mtDNAの中でも, 比較的塩基配列が保存され種 間の系統解析に都合のよい $12 \mathrm{~S}$ rRNA 遺伝子領 域およびチトクローム $\mathrm{b}$ 遺伝子領域について， PCR 産物ダイレクトシーケンス法により塩基配 列を決定し，他のネコ科 Felidae 動物種のデータ と比較した (Masuda et al., 1994; Masuda and Yoshida, 1995)。計 12 頭のイリオモテヤマネコ および計 2 頭のツシマヤマネコについて調べた結 果, 上記 2 種の遺伝子において個体変異は検出さ れなかったが，他のネコ科動物種との間では種々
の種間変異がみられた。

まず, $12 \mathrm{~S}$ rRNA 遺伝子の 373 塩基において， イリオモテヤマネコの配列はツシマヤマネコのも のと全く同一であった。さらに，この配列は調べ た東南アジア産ベンガルヤマネコ 6 頭のうちの 5 頭と全く同じであった。もう 1 頭のベンガルヤマ ネコでは, 301 番目の部位で 1 塩基の置換 $\mathrm{C} \rightarrow \mathrm{T}$ (0.3\%，1/373塩基）がみられただけであった。 これに対し，イリオモテヤマネコ・ツシマヤマネ コ・ベンガルヤマネコと他のネコ科動物種との間 では $1 \%$ 以上のちがいがみられた。

次に，チトクローム $\mathrm{b}$ 遺伝子はどうであろうか。 この遺伝子は上記の $12 \mathrm{~S} r R N A$ 遺伝子よりもさ らに速い進化速度をもっていることが知られてい る。ここでもやはり，イリオモテヤマネコ・ツシ マヤマネコ・ベンガルヤマネコの 3 者は, 互いに 極めて類似した塩基配列をもっていることが明ら かとなった（Masuda and Yoshida，1995)。ま ず, ベンガルヤマネコ 6 頭の間で個体差はみられ なかった。イリオモテヤマネコとベンガルヤマネ コの間では 2 塩基（ $0.5 \%, 2 / 402$ 塩基）の置換が みられた（図 2, 表 1)。1つは 108 番目の部位に あり, コドン（1つのアミノ酸をコードする $3 つ$ の塩基）の変化は $\mathrm{CTG} \rightarrow \mathrm{CTA}($ イリオモテヤマ ネコ $\rightarrow$ ベンガルヤマネコ) という同義突然変異 (これらのコドンがコードするアミノ酸はともに ロイシンで, 塩基配列はアミノ酸配列に影響を与 えない) であった。もう一方の置換は 354 番目部 位を含む ATA $\rightarrow$ ATGで，これも同義突然変異 (両コドンはメチオニンをコードしている) であっ た（図 2, 表 1 )。ツシマヤマネコとベンガルヤマ ネコの間では, 354 番目の部位を含むコドンにお いて, ATA $\rightarrow$ ATG（ツシマヤマネコ ベンガル ヤマネコ) の置換がみられ (0.25\%,1/402塩基), これも同義突然変異であった（図 2 , 表 1 )。イリ オモテーツシマーベンガルヤマネコのチトクローム $\mathrm{b}$ 遺伝子領域において観察された $0.25 \sim 0.5 \%$ の 塩基置換率は, 他のネコ科動物種の種内変異（個 体変異) に相当する值である。また, 他の食肉目 Carnivoraであるニホンイタチおよびニホンタヌ キのチトクローム $\mathrm{b}$ 遺伝子において検出される個 
$\begin{array}{lllllllll}10 & 20 & 30 & 40 & 50 & 60 & 70 & 80 & 90\end{array}$

仯柇 $\bar{\tau}$ ATGACCAACA TTCGAAAATC ACACCCCCTT ATCAAAATCA TCAACCACTC ATTCATCGAT CTACCTGCCC CATCCAACAT CTCAGCATGA TGGAaCTTCG

.

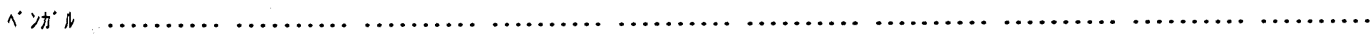

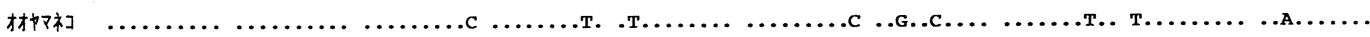

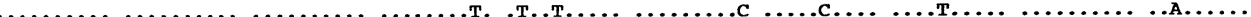

$\begin{array}{lllllllll}110 & 120 & 130 & 140 & 150 & 160 & 170 & 180 & 190\end{array}$

狮括 GCTCCCTGCT AGGAGTATGC CTAATTCTAC AAATCCTCAC CGGCCTTTTC CTAGCCATAC ACTACACATC AGATACAACA ACCGCCTTCT CATCAGTCAC

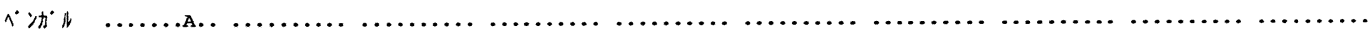

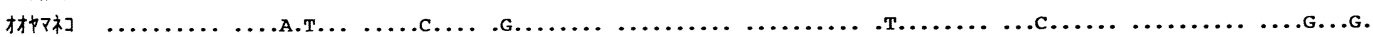

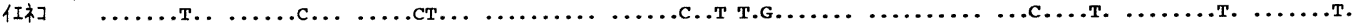

$\begin{array}{llllllllll}210 & 220 & 230 & 240 & 250 & 260 & 270 & 280 & 290\end{array}$

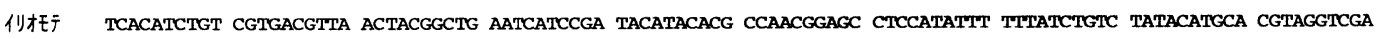

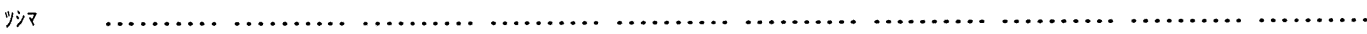

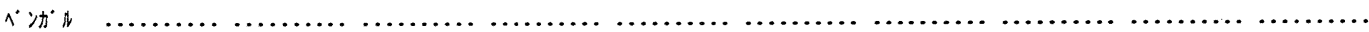

オ才ヤマ社

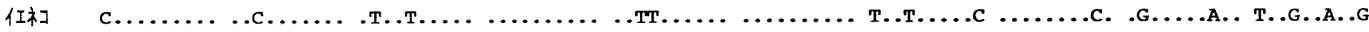

$\begin{array}{lllllllll}310 & 320 & 330 & 340 & 350 & 360 & 370 \quad 300\end{array}$

仯标 GGAATATATT ATGGCTCCTA CACCTTCTCA GAGACATGAA ACATTGGAAT CATACTGCTA TTCGCAGTCA TAGCCACAGC TTTCATGGGT TACGTACTGC CA

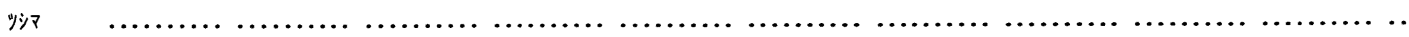

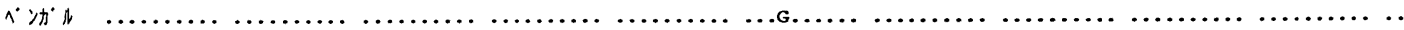

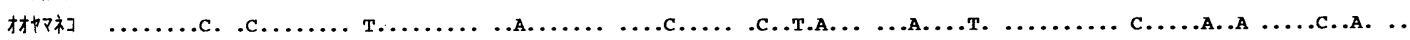

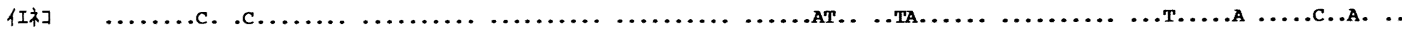

図 2 チトクローム b 遺伝子領域の塩基配列（402塩基).(Masuda and Yoshida，1995より）

最上段から，イリオモテヤマネコ，ツシマヤマネコ，ベンガルヤマネコ，オオヤマネコ，イエネコの配列 を並べた。点はイリオモテヤマネコと同じ塩基を示す. 矢印は，イリオモテーツシマーベンガルヤマネコ 間で置換のみられる 108 番目および 354 番目の部位を示す.

Fig. 2 Alignment of cytochrome b nucleotide sequences of the Iriomote cat, Tsushima cat, leopard cat, lynx, and domestic cat.

Dots indicate identity with nucleotides of the Iriomote cat. Arrows show nt 108 and 354, where nucleotide substitutions occurred among the Iriomote cat, Tsushima cat, and leopard cat.

表 1 イリオモテヤマネコ, ツシマヤマネコおよび ベンガルヤマネコのチトクローム b 遺伝子領 域（402塩基）に打塩基置換. (Masuda and Yoshida, 1995より)

Table 1 Nucleotide substitutions in the cytochrome $b$ gene region (402 bases) of the Iriomote cat, Tsushima cat, and leopard cat

\begin{tabular}{ccc}
\hline \multirow{2}{*}{ 動物名 } & \multicolumn{2}{c}{ 塩基の部位 } \\
\cline { 2 - 3 } & 108番目 & 354 番目 \\
\hline イリオモテヤマネコ & $\mathrm{G}$ & $\mathrm{A}$ \\
ツシマヤマネコ & $\mathrm{A}$ & $\mathrm{A}$ \\
ベンガルヤマネコ & $\mathrm{A}$ & $\mathrm{G}$ \\
\hline
\end{tabular}

体変異も同程度（1％前後またはそれ以下）であっ た（増田, 1994; Masuda and Yoshida, 1994a, b)。それに対して，イリオモテヤマネコ・ツシマ
ヤマネコと他のネコ科との塩基置換率は $5 \%$ 以上 となった。

ここで, 各種間の進化距離からイリオモテヤマ ネコ・ツシマヤマネコのネコ科における系統関係 を調べてみよう。図 3 は, 近隣結合法 (Saitou and Nei，1987）に基づいて作成したチトクロー 厶 $\mathrm{b}$ 遺伝子の分子系統樹である（Masuda and Yoshida, 1995; Masuda et al., in press)。こ れは無根系統樹で, 種間の枝の道のりが進化距離 (塩基置換数)を表わしている。また，樹上の数值 （\%）はブーツストラップ值（Felsenstein, 1985) で，この值が大きい程（最高 $100 \%$ ）その枝分か れの信頼度が高い。樹形から明らかなように，調 べたネコ科は大きく, アジア産ヤマネコ類, 南米 産ネコ類 (オセロット系列), イエネコ系列, パン セラ属Pantheraを含む大型ネコ類のグループに 


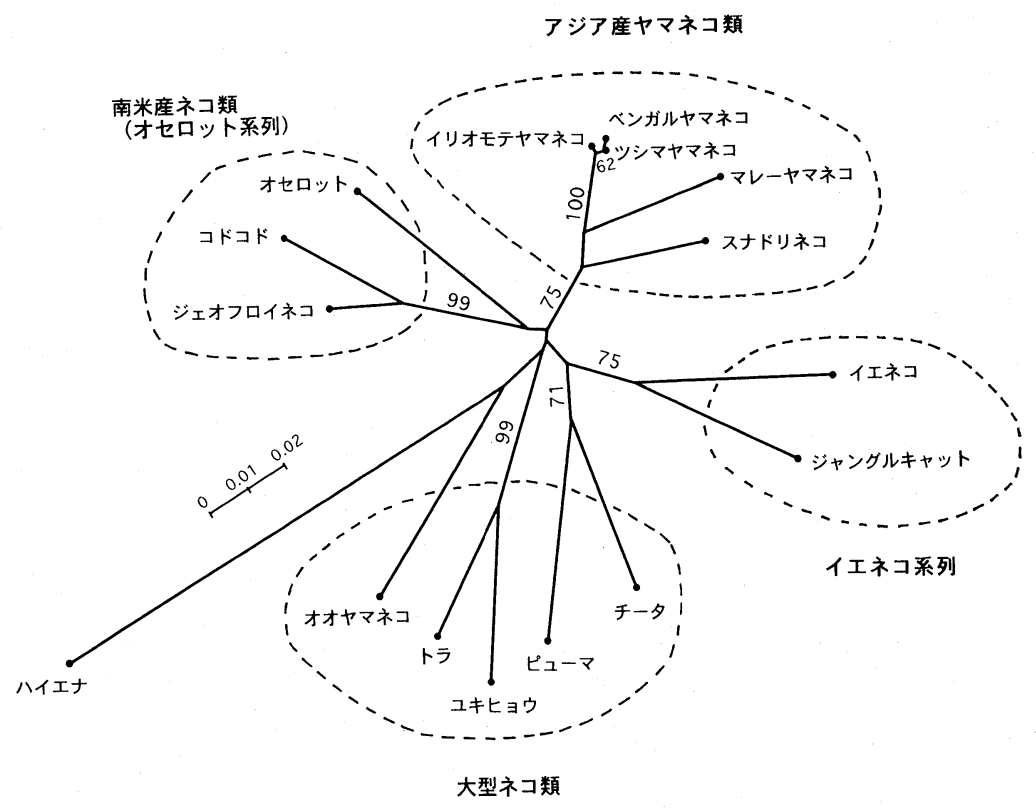

図 3 近隣結合法によるチトクローム b遺伝子の分子系統樹.

(Masuda and Yoshida, 1995; Masuda et al., in press より改作)

種と種をつなぐ線の道のりが進化距離であり，その距離が短い程，近縁であることを表わ している。進化距離には，二変数法（Kimura，1980）によって補正した1部位当たりの塩 基置換数（スケールは目盛付き棒線）を用いた。枝上の数值（％）は，1,000回繰り返した ときのブーッストラップ值（Felsenstein, 1985）で，值が大きい程（最高 $100 \%$ ）枝分か れの信頼度が高い.アジア産ヤマネコ類が，ひとつのグループを形成している。その中で も，イリオモテーツシマ-ベンガルヤマネコが極めて近縁であり，これら 3 者のグループは $100 \%$ \%信頼度をもって支持された. 外群として, ネコ科に近いハイエナ科を用いた.

Fig. 3 Molecular phylogenetic tree of cytochrome $b$ sequences constructed by the neighbor-joining method.

Distance between species and species shows phylogenetic relationships between them. Numbers of nucleotide substitutions per site (indicated by scale) estimated using the Kimura's two parameter method were used as the distance. Bootstrap values above branches were derived from 1,000 replications. Close relationship between the Iriomote cat, Tsushima cat, and leopard cat was supported with 100 $\%$ bootstrap value.

分かれた。この分子系統は, 従来の形態分類とほ ぼ一致する。アジア産ヤマネコ類（イリオモテ， ツシマ, ベンガル, マレーヤマネコ，スナドリネ コを含む）のグループは，高い信頼度（ブーツス トラップ值 $75 \%$ ）をもって支持された。これら アジア産ヤマネコ類は, 従来の分類においてもプ リオナイルルス属 Prionailurus (または亜属)と して 1 つのグループにされることが多い。その中 でも，イリオモテーツシマーベンガルヤマネコ 3 者 のグループは, 信頼度 $100 \%$ をもて支持され， かつ，これら 3 者が互いに極めて近縁であること
が明白である。また，これら 3 者とマレーヤマネ コおよびスナドリネコとの進化距離は約 4 $5 \%$ 程度であるのに対し，これら 3 者と他のネコ科と は $10 \%$ 前後またはそれ以上の進化距離があった。

また, Suzuki et al. (1994) は細胞核内のリボ ソーム DNA 領域における制限酵素断片長多型を 分析し, イリオモテヤマネコとベンガルヤマネコ (シベリア産) の間で変異のないことを報告して いる。

以上述べてきた分子系統解析の結果は，イリオ モテヤマネコとッシマヤマネコがアジア大陸に分 
表 2 イリオモテヤマネコ, ツシマヤマネコ, ベンガルヤマネコおよびその他のネコ科種間の塩基置換率 (観察值). (Masuda et al., 1994; Masuda and Yoshida, 1995より)

Table 2 Percentage differences of the cytochrome $b$ nucleotide sequenses among the Iriomote cat, Tsushima cat, leopard cat, and other feline species.

\begin{tabular}{llllllll}
\hline \multicolumn{1}{c}{ 種名 } & 1 & 2 & 3 & 4 & 5 & 6 & 7 \\
\hline 1. イリオモテヤマネコ & 0 & 0.25 & 0.5 & 10.4 & 11.2 & 13.2 & 12.9 \\
2. ツシマヤマネコ & & 0 & 0.25 & 10.7 & 11.2 & 13.4 & 13.2 \\
3. ベンガルヤマネコ & & & 0 & 11.0 & 11.4 & 13.7 & 13.4 \\
4. オオヤマネコ & & & & 0 & 11.9 & 13.7 & 11.4 \\
5. イエネコ & & & & & 0 & 12.2 & 12.4 \\
6. ユキヒョウ & & & & & 0 & 6.7 \\
7. ト ラ & & & & & & & 0 \\
\hline
\end{tabular}

布するベンガルヤマネコに遺伝的に極めて近縁で あることを示し，両ヤマネコをベンガルヤマネコ と同種に扱う分類を支持している。両ヤマネコの 形態的特徵と進化距離を考慮すると, iriomotensis と euptilura は Felis bengalensisの 亜種名として扱われるのが妥当と思われる。

\section{V. イリオモテャマネコの分岐年代と西表島の 形成年代との比較}

ここで，これまでに得られた塩基配列に基づい てネコ科における遺伝子の進化速度を計算し，イ リオモテヤマネコーベンガルヤマネコ間の分岐年 代を推定してみよう。ネコ科を含む食肉目につい ては化石デー夕および生化学・分子生物学的分析 により，各種間の分岐年代が推定されている (Wayne et al., 1991)。それによると, イエネコ とトラの分岐年代は今からおよそ 450 万年前であ る。いま, 分子進化学的に $\mathrm{T}=\mathrm{D} / 2 \mathrm{~V}$ （T：分岐年 代, D: 進化距離， $\mathrm{V}$ : 進化速度) が成り立つ。よっ て, 塩基置換速度がネコ科内でほぼ一定と仮定す ると, イエネコとトラのチトクローム b 遺伝子の 塩基置換が $12.4 \%$ \%ある（表 2 ）ことから，ネコ 科のチトクローム $\mathrm{b}$ 遺伝子の塩基置換速度 $(\mathrm{V})$ は $1.38 \% / 100$ 万年 $[=12.4 \% /(2 \times 450$ 万年 $)]$ と算出される。次に，イリオモテヤマネコとベン ガルヤマネコとの間の塩基置換は $0.5 \%$ である （表2）。したがって，両ヤマネコの分岐年代 (T) は扰よそ 18 万年 $[=0.5 \% /(2 \times 1.38 \% / 100$ 万 年)］前と計算される。また, 哺乳類全般を通し
てのチトクローム $\mathrm{b}$ 塩基配列の多様度は，100万 年当たり少なくとも $2.5 \%$ と報告されている (Meyer et al., 1990; Irwin et al., 1991) ので, この值を用いると両ヤマネコの分岐年代は 20 万 年 $[100$ 万年 $\times 0.5 \% / 2.5 \%]$ 以内と推定される。 このように，2つの異なる方法によって算出され た両ヤマネコの分岐年代はよく一致した。

一方，最近の木村ほか（1992）の海洋地質学的 調査によって, 今からおよそ 24 万〜 万年前には 琉球弧とアジア大陸との間で断続的に陸橋が形成 されていたことが明らかになってきた。このよう に, 南西諸島の地質学的形成年代が分子系統学的 に得られたイリオモテーベンガルヤマネコの分岐 年代と一致することは，筆者らの分子系統学的分 析の高い信頼性を示すものである。事実，西表島 から西方約 $200 \mathrm{~km}$ の地点に位置する台湾にはべ ンガルヤマネコに分類されるヤマネコが分布して おり，陸続きの時代には両ヤマネコの祖先集団の 間で遺伝的交流があったのであろう。

今泉ほか（1977）は，イリオモテヤマネコの頭 骨形態がメタイルルス属に類似しているとみなし， イリオモテヤマネコが今から 300 万年以上前にア ジア大陸から西表島へ渡来したと想像している。

しかし，筆者らが分子系統学的デー夕に基づいて 算出した渡来時期は約 20 万年前後という新しい ものであり，これは南西諸島の陸橋に関する最近 の新しい知見によっても支持される。また，筆者 らの遺伝子分析は，イリオモテヤマネコの祖先が アジア大陸に現存しているベンガルヤマネコ集団 
であることを強く裏付けた。

「なぜ南西諸島の島々の中で西表島にのみヤマ ネコが生息しているのか」は今のところ不明であ る。沖縄県教育委員会（1985）の報告書によると， 西表島の東北東約 $140 \mathrm{~km}$ の地点にある宮古島で はイリオモテヤマネコかどうかは定かではないが, ヤマネコと思われる化石が発見されている。今後, 南西諸島における詳細な古生物学的調査が進めば, イリオモテヤマネコの祖先の渡来経路に関する謎 が解き明かされるであろう。

\section{VI. ツシマヤマネコの分岐年代と対馬の 形成年代との比較}

さて, ツシマヤマネコとベンガルヤマネコの分 岐年代はどうであろうか。チトクローム b 遺伝子 における，ツシマヤマネコーベンガルヤマネコ間 の塩基置換は，イリオモテヤマネコーベンガルヤ マネコ間の值の半分, すなわち $0.25 \%$ である（表 2)。これを基にして, 上述のイリオモテヤマネコ の分岐年代推定と同様の手順をふめば，ツシマヤ マネコがベンガルヤマネコと分岐したのは，今か ら抢よそ9 10 万年前と推定される。一方，大嶋 （1990，1991）は，海水準の変動に基づいて日本列 島周辺の海峡形成年代を推定している。それによ ると, 対馬を挟む対馬海峡掞よび朝鮮海峡が形成 されたのは，およそ10 万年前である。この海峡 形成年代は，筆者らが遺伝子データから求めたツ シマヤマネコーベンガルヤマネコの分岐年代と一 致している。この結果は, 対馬が形成されるまで には, ツシマヤマネコの祖先と大陸のベンガルヤ マネコの集団との間で遺伝的交流があったことを 物語っている。事実, 対馬が朝鮮海峡を挟んで向 かい合う朝鮮半島には, ベンガルヤマネコが分布 している。また, 対馬の隣に位置する済州島（韓 国）（図 1）にもヤマネコが生息していたが，ごく 最近，生息域の破壊により絶滅したといわれる。 なぜ, ツシマヤマネコは九州・本州などに分布し ていないのかは謎である。ツシマヤマネコ集団が 対馬に渡来したときには，すでに形成された対馬 海峡によって行く手を阻まれたのかもしれない。 対馬にはシベリアイタチなど大陸と共通する動物
が分布しているため，このような種についても分 析を進めることにより, 対馬の動物の渡来と進化 がさらに明らかになってくるものと考える。

\section{VII. ま と め}

以上紹介した日本産ヤマネコの分子系統に関す る研究成果をまとめると, 次の 2 点になる。

1) ミトコンドリアDNAの分子系統学的解析 により，イリオモテヤマネコおよびッシマヤマネ コが, ネコ科においてアジア大陸のベンガルヤマ ネコと遺伝的に極めて近縁であることが明らかに なった。その進化距離は, 他のネコ科動物種の種 内変異に相当した。しかし，日本産ヤマネコは， 各々, 西表島と対馬において独自の進化をとげ, 特徵的な形態・性質をもっていることから, 貴重 なヤマネコ集団であることは明らかであり，保護 管理していく必要がある。

2）DNA デー夕に基づき, イリオモテヤマネコー ベンガルヤマネコ間掠よびッシマヤマネコーベン ガルヤマネコ間の分岐年代を推定すると, 各々, 今からおよそ 20 万年前ならびに 10 万年前と算出 された。これらの分岐年代は, 各々, 西表島を含 む南西諸島および対馬の地質学的形成年代とほぼ 一致した。遺伝子分析から推定される分岐年代と 地質学的データとの統合が, 日本列島の地史を考 察する上で有効であることが示された。

今後は, さらに, 日本列島に分布する生物種と 大陸の生物種とを分子系統学的に比較解析してい くと同時に, 地質学的・古生物学的知見と照らし 合わせることにより, 日本列島への生物の渡来と 進化および日本列島の地史がより明らかにされて いくものと考える。

\section{謝 辞}

貴重な標本をご提供いただきました以下の方々に媣く 御礼申し上げます: 伊澤雅子助教授 (琉球大学理学部), 阿久沢正夫教授 (鹿児島大学農学部), 岡田雄一氏 (長 崎県対馬支庁), 伊東員義氏, 鈴木 仁氏 (東京都上野 動物園), 小松 守氏 (秋田市大森山動物園)。また, 貴 重なご助言をいただきました米田政明博士（自然環境研 究センター)に感謝いたします。本研究の一部は, 文部 
省科学研究費および稲盛財団助成によってサポートされ ました。

\section{文献}

Brown, W.M., George, M.Jr. and Wilson, A.C. (1979): Rapid evolution of animal mitochondrial DNA. Proc. Natl. Acad. Sci. USA, 76, 1967-1971.

Ewer, R.F. (1973): The carnivores. Cornell Univ. Press, New York, 494p.

Felsenstein, J. (1985): Confidence limits on phylogenies: An approach using the bootstrap. Evolution, 39, 783-791.

Gyllensten, U.B. and Erlich, H.A. (1988): Generation of single-stranded DNA by the polymerase chain reaction and its application to direct sequencing of the HLA-DQA locus. Proc. Natl. Acad. Sci. USA, 85, 7652-7656.

Hemmer, H. (1978): The evolutionary systematics of living Felidae: Present status and current problems. Carnivore, 1, 71-79.

Imaizumi, Y. (1967): A new genus and species of cat from Iriomote, Ryukyu Islands. $J$. Mamm. Soc. Japan, 3, 75-108.

今泉吉典・今泉忠明・茶畑哲夫 (1977): イリオモテヤ マネコの生態及び保護に関する研究，第三次報告. 環 境庁, $129 \mathrm{p}$.

Irwin, D.M., Kocher, T.D. and Wilson, A.C. (1991): Evolution of the cytochrome b gene of mammals. J. Mol. Evol., 32, 128-144.

Kimura, M. (1980): A simple method for estimating evolutionary rate of base substitutions through comparative studies of nucleotide sequences. J. Mol. Evol., 16, 111-120.

木村政昭 - 松本 剛 - 中村俊夫 - 大塚裕之 - 西田史朗 青木美澄・小野朋典・段野洲興 (1992): 沖縄卜ラフ 東縁ケラマ鞍部の潜水調査一ウルム氷期の陸橋か？ 一. 第 8 回しんかいシンポジウム報告書, 107-133.

Kocher, T.D., Thomas, W.K., Meyer, A., Edwards, S.V., Pääbo, S., Villablanca, F.X. and Wilson, A.C. (1989): Dynamics of mitochondrial DNA evolution in animals: Amplification and sequencing with conserved primers. Proc. Natl. Acad. Sci. USA, 86, 6196 -6200 .

Leyhausen, P. (1979): Cat behavior. Garland STPM Press, New York, 340p.

増田隆一 (1994): 食肉類におけるミトコンドリア DNA の塩基配列解析： PCR 法の活用と分子系統へ の応用一イリオモテヤマネコおよびイタチ科を中心 にして一. 哺乳類科学, 34, 81-89.

Masuda, R. and Yoshida, M.C. (1994a): A molecular phylogeny of the family Mustelidae (Mammalia, Carnivora), based on comparison of mitochondrial cytochrome $b$ nucleotide sequences. Zool. Sci., 11, 605-612.

Masuda, R. and Yoshida, M.C. (1994b): Nucleotide sequence variation of cytochrome $\mathrm{b}$ genes in three species of weasels Mustela itatsi, Mustela sibirica, and Mustela nivalis, detected by improved PCR product-direct sequencing technique. J. Mamm. Soc. Japan, 19, 33-43.

Masuda, R. and Yoshida, M.C. (1995): Two Japanese wildcats, the Tsushima cat and the Iriomote cat, show the same mitochondrial lineage as the leopard cat Felis bengalensis. Zool. Sci., 12, 655-659.

Masuda, R., Yoshida, M.C., Shinyashiki, F. and Bando, G. (1994): Molecular phylogenetic status of the Iriomote cat Felis iriomotensis, inferred from mitochondrial DNA sequence analysis. Zool. Sci., 11, 597-604.

Masuda, R., Lopez, J. V., Pecon Slattery, J., Yuhki, N. and O' Brien, S. J. (in press): Molecular phylogeny of mitochondrial cytochrome $\mathrm{b}$ and $12 \mathrm{~s}$ rRNA sequences in the Felidae: Ocelot and domestic cat lineaqes. Mol. phylogenet. Evol.

Meyer, A., Kocher, T.D., Basasibwaki, P. and Wilson, A.C. (1990): Monophyletic origin of Lake Victoria cichlid fishes suggested by mitochondrial DNA sequences. Nature, 347, 550-553.

Mullis, K., Faloona, F., Scharf, S., Saiki, R., Horn, G. and Erlich, H. (1986): Specific enzymatic amplification of DNA in vitro: The polymerase chain reaction. Cold Spring Harbor Symp. Quant. Biol., 51, 263-273.

Nowak, R.M. (1991): Walker's mammals of the world. 5th ed. Johns Hopkins Univ. Press, Baltimore, 1629p.

大嶋和雄 (1990): 第四紀後期の海峡形成史. 第四紀研 究, 29, 193-208.

大嶋和雄 (1991): 第四紀後期における日本列島周辺の 海水準変動. 地学雑誌, 100, 967-975.

沖縄県教育委員会 (1985): 沖縄県文化財調査報告書第 68集. ピンザブ: ピンザアブ洞穴発掘調查報告. $184 \mathrm{p}$.

Saiki, R.K., Gelfand, D.H., Stoffel, S., Scharf, S.J., Higuchi, H., Horn, G.T., Mullis, K.B. and Erlich, H.A. (1988): Primer-directed enzymatic amplification of DNA with a thermostable DNA polymerase. Science, 239, 487-491.

Saitou, N. and Nei, M. (1987): The neighborjoining method: A new method for reconstructing phylogenetic trees. Mol. Biol. Evol., 4, 406-425.

Suzuki, H., Hosoda, T., Sakurai, S., Tsuchiya, K., Munechika, I. and Korablev, V.P. (1994): Phylogenetic relationship between the Iriomote cat and the leopard cat, Felis bengalensis, based on the ribosomal DNA. 
Japan. J. Genet., 69, 397-406.

Wayne, R.K., Van Valkenburgh, B. and O'Brien, S.J. (1991): Molecular distance and divergence time in carnivores and primates. Mol. Biol. Evol., 8, 297-319.

Wozencraft, W.C. (1993): Order Carnivora. In Wilson, D.E. and Reeder D.M. eds.: Mammal species of the world: A taxonomic and geographic reference. 2nd ed. Smithsonian Institution Press, Washington, 279-348.

Wurster-Hill, D.H., Doi, T., Izawa, M. and Ono, Y. (1987): Banded chromosome study of the Iriomote cat. J. Hered., 78, 105-107.

(1995 年 11 月 20 日受付, 1996 年 2 月 19 日受理) 